Tropical Journal of Pharmaceutical Research June 2015; 14 (6): 1089-1094

ISSN: $1596-5996$ (print); 1596-9827 (electronic)

(C) Pharmacotherapy Group, Faculty of Pharmacy, University of Benin, Benin City, 300001 Nigeria.

All rights reserved.

Available online at http://www.tjpr.org

Original Research Article

http://dx.doi.org/10.4314/tjpr.v14i6.22

\title{
Extended-Spectrum Beta-Lactamase (ESBL)-Producing Gram-negative Isolates from Urine and Wound Specimens in a Tertiary Health Facility in Southern Nigeria
}

\author{
Helen O Ogefere ${ }^{1 *}$, Patience A Aigbiremwen ${ }^{1}$ and Richard Omoregie ${ }^{2}$ \\ ${ }^{1}$ Department of Medical Laboratory Science, School of Basic Medical Sciences, College of Medical Sciences, University of \\ Benin, ${ }^{2}$ School of Medical Laboratory Sciences, University of Benin Teaching Hospital, Benin City, Nigeria
}

*For correspondence: Email: helenogefere@yahoo.com

Received: 21 March 2015

Revised accepted: 23 May 2015

\begin{abstract}
Purpose: To determine the prevalence of extended spectrum beta lactamase (ESBL) producing Gram negative bacteria causing wound and urinary tract infections among in- and out-patients in a tertiary health facility.

Methods: The presence of ESBL was determined among 230 Gram negative bacilli isolated from wound (105) and urine (125) specimens from in- and out-patients who attended University of Benin Teaching Hospital (UBTH) for treatment using the double disc synergy method. Disc susceptibility test was performed on all isolates using standard techniques.

Results: There was no significant difference in the prevalence of ESBL production between isolates from wound (47.6 \%) and urine (41.6\%) as well as between in-patients (48.8\%) and out-patients (39.38\%). Enterobacter species were the most prevalent producers of ESBL from both wound and urine specimens as well as from both in- and out-patients. Bacterial isolates that produced ESBL were more resistant to amoxicillin-clavulanate, ceftazidime, ceftriaxone, cefotaxime, gentamicin, ciprofloxacin and ofloxacin compared to non-ESBL producers.

Conclusion: A high prevalence (44.3\%) of ESBL producing Gram-negative bacteria was observed among the patients, with Enterobacter species being the most prevalent. Prudent use of antibacterial agents is advocated to stem the tide.
\end{abstract}

Keywords: Extended-spectrum beta-lactamase, Enterobacter species, Wound, Urine, Gram negative bacteria

Tropical Journal of Pharmaceutical Research is indexed by Science Citation Index (SciSearch), Scopus, International Pharmaceutical Abstract, Chemical Abstracts, Embase, Index Copernicus, EBSCO, African Index Medicus, JournalSeek, Journal Citation Reports/Science Edition, Directory of Open Access Journals (DOAJ), African Journal Online, Bioline International, Open-J-Gate and Pharmacy Abstracts

\section{INTRODUCTION}

Antibiotic resistance of bacteria is commonly seen in daily medical practice with multi-drug resistant Gram negative bacteria posing the greatest threat to human health [1]. Beta lactam antibiotics are the most predominantly prescribed antibiotics to treat bacterial infections, especially in Nigeria hospitals [1,2]. $\beta$-lactamases are major defense of Gram negative bacteria against $\beta$ lactam antibiotics [3]. Extended spectrum $\beta$ - lactamases (ESBL), a type of $\beta$-lactamase, are typically inhibitor-susceptible $\beta$-lactamase that hydrolyze penicillins, cephalosporins and aztreonam [3], and are encoded by mobile gene [4]. These genes often code resistance to cephalosporins and other antibiotics such as aminoglycosides, fluoroquinolones, tetracyclines, chloramphenicol and sulfamethoxazoletrimetroprim [5]. 
Infections caused by ESBL-producing Gram negative bacteria are associated with increased morbidity and mortality which is linked to inappropriate or delayed antimicrobial treatment [6]. Risk factors that have been associated with ESBL production include old age (> 65 years), male gender, previous use of $\beta$-lactam antibiotics and fluoroquinolones amongst others [6,7]. In Nigeria, extended-spectrum cephalosporins and fluoroquinolones are widely used as broadspectrum antibiotics and remain the drugs of choice to treat infections caused by various Gram negative pathogens [8]. Also, antibiotics use in Nigeria is unregulated and over the counter sales of antibiotics without prescriptions are rife [9-11]. These indicate that ESBL producing organisms may be rife in Nigeria and indeed reports of ESBL-producing Gram negative bacteria exists [11].

A previous study from Benin City, Nigeria reported a prevalence of $2.7 \%$ of ESBL producing Gram negative bacteria from blood stream infections and surgical wounds [12]. However, that study, only evaluated ceftazidime as the only indicator of ESBL production. Ceftazidime is a good indicator of TEM (Temoniera) and SHV (Sulphydryl) type of ESBL and not the CTX-M (Cefotaximase - Munich) type [13]. The CTX-M type is detected with the use of cefotaxime [13]. It has been reported that Gram-negative bacteria cause a significant number of infections in Nigerian hospitals and represent the majority of both wound and urinary isolates, which form the largest group of specimens received in microbiology laboratories [11]. These will indicate that the study of Omoregie et al [12], may have underestimated the true prevalence of ESBL. Against this background, this study aimed to determine the prevalence of ESBL among Gram negative bacteria causing wound and urinary tract infections among community and hospital isolates. The susceptibility patterns of all the isolates were also determined.

\section{EXPERIMENTAL}

\section{Bacterial isolates}

A total of 230 consecutive non-repetitive bacterial isolates from wound (105) and urinary tract infections (125) collected from patients attending University of Benin Teaching Hospital, Benin City (UBTH) were used for this study. One hundred and twenty three (123) of these isolates were recovered from in-patients while 107 isolates were from out-patients. The isolates included Escherichia coli, Klebsiella species, Citrobacter species, Enterobacter species, Proteus mirabilis, Proteus vulgaris, Providencia species, Acinetobacter species and Pseudomonas aeruginosa. All isolates were identified using standard techniques [14].

\section{ESBL detection}

The presence of ESBL was detected in all isolates using the double disc test [13]. Briefly, test organisms were emulsified in sterile water and the turbidity matched with $0.5 \mathrm{McF}$ arland standards. Once matched, a sterile cotton wool swab was dipped in the organism suspension and excess liquid was removed by turning the swab on side of the test tube. The entire surface of Mueller-Hinton agar plate was seeded by swabbing in three directions with the swab. A disc containing $30 \mu \mathrm{g}$ amoxicillin-clavulanate (Oxoid, England) was placed at the centre of the agar plate. A $30 \mu \mathrm{g}$ ceftazidime disc (Oxoid, England) was placed $25 \mathrm{~mm}$ from the amoxicillin-clavulanate disc and another disc containing $30 \mu \mathrm{g}$ cefotaxime (Oxoid, England) was placed on the opposite side of the amoxicillin-clavulanate disc ( $25 \mathrm{~mm}$ apart). The plates were incubated at $37{ }^{\circ} \mathrm{C}$ overnight and ESBL production was inferred as positive if there was an expansion of the zone of inhibition between the ceftazidime and amoxicillinclavulanate disc, cefotaxime and amoxicillinclavulanate disc or both.

\section{Disc susceptibility testing}

Disc susceptibility tests were performed on all bacterial isolates using the British Society for Antimicrobial Chemotherapy (BSAC) method [15].

\section{Statistical analysis}

The data obtained were analyzed with chi square $\left(\mathrm{X}^{2}\right)$ test and odd ratio analysis using the statistical software Instat (R) (Graph Pad Software Inc, La Jolla, CA, USA).

\section{RESULTS}

A total of $102(44.3 \%)$ out of the 230 isolates produced ESBL. Of these isolates that were positive for ESBL, 97 (95.1\%) were indicated by both ceftazidime and cefotaxime, while 5 (4.9\%) were indicated by cefotaxime alone. Generally and among individual isolates (with the exception of Citrobacter species), there was no significant difference in EBSL production among isolates from wounds and urinary tract infections. EBSL 
production by Citrobacter species was more likely to occur from the bacteria isolated from wounds as compared to urinary tract infections. $(\mathrm{OR}=55.000,95 \% \mathrm{Cl}=0.828,3654.5, p=$ 0.0476). Enterobacter species were the most prevalent producers of ESBL generally whether from wound, and urine specimens (Table 1).

Isolates of Enterobacter species from both inpatients and out-patients were the most predominant producers of ESBL in comparison to other isolates. Although Gram negative isolates from in-patients $(48.8 \%)$ had higher prevalence of ESBL production than others recovered from out-patients $(39.3 \%)$ and were more likely to produce ESBL $(\mathrm{OR}=1.474,95 \% \mathrm{Cl}=0.872$, 2.492); this was not statistically significant $(P=$ 0.1833 ) (Table 2).

The susceptibility profiles of ESBL-producing and non-ESBL-producing Gram negative bacterial isolates are shown in Table 3 and 4 respectively. Generally, isolates that produce EBSL were more resistant to the antimicrobials used compared with non-ESBL producers. Imipenem was the most active antibiotic against ESBL-producing and non-ESBL-producing Gram negative bacteria.

\section{DISCUSSION}

Of the 102 Gram negative bacteria that produced ESBL, $97(95.1 \%)$ were detected by both ceftazidme and cefotaxime. This will indicate that majority of the isolates producing ESBL in this study produce multiple types of ESBL such as TEM, SHV and CTX-M types. Indeed previous studies have reported both TEM, SHV and CTX$M$ types of ESBL in Nigeria [8,17]. Five isolates $(4.9 \%)$ produced only CTX-M type. This indicates that the CTX-M type of ESBL were more predominant in this study and agrees with previous reports from other Nigerian studies

Table 1: Prevalence of ESBL production in relation to specimen

\begin{tabular}{lcccccc}
\hline Organism & $\begin{array}{c}\text { No. } \\
\text { tested }\end{array}$ & $\begin{array}{c}\text { Wound } \\
\text { No. positive } \\
(\%)\end{array}$ & $\begin{array}{c}\text { No. } \\
\text { tested }\end{array}$ & $\begin{array}{c}\text { Urine } \\
\text { No. positive } \\
(\%)\end{array}$ & $\begin{array}{c}\text { No. tested } \\
\text { No. positive } \\
(\%)\end{array}$ \\
\hline Escherichia coli & 25 & $12(48.0)$ & 54 & $24(44.4)$ & 79 & $36(45.6)$ \\
Klebsiella species & 25 & $14(56.0)$ & 23 & $7(30.4)$ & 48 & $21(43.8)$ \\
Citrobacter species & 2 & $2(100.0)$ & 5 & $0(0.0)$ & 7 & $2(28.6)$ \\
Enterobacter species & 1 & $1(100.0)$ & 8 & $7(87.5)$ & 9 & $8(88.9)$ \\
Proteus mirabilis & 12 & $3(25.0)$ & 4 & $2(50.0)$ & 16 & $5(31.3)$ \\
Proteus vulgaris & 8 & $3(37.5)$ & 8 & $3(37.5)$ & 16 & $6(37.5)$ \\
$\begin{array}{l}\text { Providencia species } \\
\text { Acinetobacter species }\end{array}$ & 2 & $0(0.0)$ & 5 & $1(20.0)$ & 7 & $1(14.3)$ \\
Pseudomonas & 6 & $2(33.3)$ & 12 & $5(41.7)$ & 18 & $7(44.4)$ \\
aeruginosa & 24 & $13(54.2)$ & 6 & $3(50.0)$ & 30 & $16(53.3)$ \\
\hline Total & 105 & $50(47.6)$ & 125 & $52(41.6)$ & 230 & $102(44.3)$ \\
\hline *Wound vs urine: OR 55.000, 95\% Cl=0.8278, 36545; $p=0.0476$ OR = odd ratio, Cl = confidence interval
\end{tabular}

Table 2: Prevalence of ESBL production in relation to patients

\begin{tabular}{|c|c|c|c|c|c|c|c|}
\hline \multirow[t]{2}{*}{ Organism } & \multicolumn{2}{|c|}{ In-patient } & \multicolumn{2}{|c|}{ Out-patient } & \multirow[b]{2}{*}{ OR } & \multirow[b]{2}{*}{$95 \% \mathrm{Cl}$} & \multirow[b]{2}{*}{$P$ value } \\
\hline & $\begin{array}{c}\text { No. } \\
\text { tested }\end{array}$ & $\begin{array}{l}\text { No. positive } \\
(\%)\end{array}$ & $\begin{array}{c}\text { No. } \\
\text { tested }\end{array}$ & $\begin{array}{l}\text { No. positive } \\
(\%)\end{array}$ & & & \\
\hline Escherichia coli & 36 & $16(44.4)$ & 43 & $20(46.5)$ & 0.920 & $0.378-2.240$ & 1.0000 \\
\hline Klebsiella species & 29 & $13(44.8)$ & 19 & $8(42.1)$ & 1.117 & $0.347-3.595$ & 1.0000 \\
\hline Citrobacter species & 4 & $2(50.0)$ & 3 & $0(0.0)$ & 7.000 & $\begin{array}{l}0.224- \\
219.13\end{array}$ & 0.4286 \\
\hline Enterobacter species & 4 & $3(75.0)$ & 5 & $5(100.0)$ & 0.212 & $0.007-6.822$ & 0.4444 \\
\hline Proteus mirabilis & 12 & $4(33.3)$ & 4 & $1(25.0)$ & 1.500 & $\begin{array}{l}0.116- \\
19.450\end{array}$ & 1.0000 \\
\hline Proteus vulgaris & 6 & $4(66.7)$ & 10 & $2(20.0)$ & 8.000 & $\begin{array}{l}0.803- \\
79.700\end{array}$ & 0.1181 \\
\hline Providencia species & 1 & $0(0.0)$ & 6 & $1(16.7)$ & 1.222 & $\begin{array}{l}0.031- \\
48.244\end{array}$ & 1.0000 \\
\hline Acinetobacter species & 8 & $4(50.0)$ & 10 & $3(30.0)$ & 2.333 & $\begin{array}{l}0.336- \\
16.188\end{array}$ & 0.6305 \\
\hline $\begin{array}{l}\text { Pseudomonas } \\
\text { aeruginosa }\end{array}$ & 23 & $14(60.9)$ & 7 & $2(28.6)$ & 3.889 & $\begin{array}{l}0.617- \\
24.529\end{array}$ & 0.2040 \\
\hline Total & 123 & $60(48.8)$ & 107 & $42(39.3)$ & 1.474 & $0.872-2.492$ & 0.1833 \\
\hline
\end{tabular}


Table 3: Susceptibility profiles of ESBL producing isolates

\begin{tabular}{|c|c|c|c|c|c|c|c|c|}
\hline \multirow[t]{2}{*}{ Organism } & \multicolumn{8}{|c|}{ Antibacterial disc $(\mu \mathrm{g} / \mathrm{disc})$} \\
\hline & $\begin{array}{r}\text { AUG } \\
(30)\end{array}$ & $\begin{array}{r}\text { CAZ } \\
(30)\end{array}$ & $\begin{array}{r}\text { CRO } \\
(30) \\
\end{array}$ & $\begin{array}{r}\text { CTX } \\
(30)\end{array}$ & $\begin{array}{l}\text { IPM } \\
(10)\end{array}$ & $\begin{array}{l}\text { CN } \\
(10)\end{array}$ & $\begin{array}{r}\text { CIP } \\
(5)\end{array}$ & $\begin{array}{c}\text { OFX } \\
(5)\end{array}$ \\
\hline Escherichia coli $(\mathrm{n}=36)$ & $2(5.6)$ & $6(16.7)$ & $2(5.6)$ & $0(0.0)$ & $26(72.2)$ & $11(30.6)$ & $6(16.7)$ & $6(16.7)$ \\
\hline Klebsiella species $(n=21)$ & $1(4.8)$ & $1(4.8)$ & $1(4.8)$ & $2(9.5)$ & $11(52.4)$ & $0(0.0)$ & $3(14.3)$ & $1(4.8)$ \\
\hline Citrobacter species $(n=2)$ & $0(0.0)$ & $0(0.0)$ & $0(0.0)$ & $0(0.0)$ & $2(100.0)$ & $1(50.0)$ & $0(0.0)$ & $0(0.0)$ \\
\hline Enterobacter species $(\mathrm{n}=8)$ & $0(0.0)$ & $0(0.0)$ & $0(0.0)$ & 1 (12.5) & $7(87.5)$ & $1(12.5)$ & $3(37.5)$ & $2(25)$ \\
\hline Proteus mirabilis $(\mathrm{n}=5)$ & $2(40.0)$ & $1(20.0)$ & $0(0.0)$ & $1(20.0)$ & $5(100.0)$ & $1(20.0)$ & $1(20.0)$ & $1(20.0)$ \\
\hline Proteus vulgaris $(\mathrm{n}=6)$ & $0(0.0)$ & $1(16.7)$ & $0(0.0)$ & $0(0.0)$ & $3(50.0)$ & $1(16.7)$ & $0(0.0)$ & $0(0.0)$ \\
\hline Providencia species $(n=1)$ & $0(0.0)$ & $1(100.0)$ & $0(0.0)$ & $1(100.0)$ & $1(100.0)$ & $1(100.0)$ & $1(100.0)$ & $1(100.0)$ \\
\hline Acinetobacter species $(n=7)$ & $0(0.0)$ & $1(14.3)$ & $1(14.3)$ & $0(0.0)$ & $3(42.9)$ & $1(14.3)$ & $0(0.0)$ & $0(0.0)$ \\
\hline Pseudomonas aeroginosa & $0(0.0)$ & $4(24.0)$ & $0(0.0)$ & $0(0.0)$ & $7(43.8)$ & $2(12.5)$ & $1(6.3)$ & $5(31.3)$ \\
\hline
\end{tabular}

Number tested, $A U G=$ Amoxicillin-clavulanate, CAZ=ceftazidime, CRO=Ceftriaxone, CTX=Cefotaxime, PM=Imipenem, CN=Gentamicin, CIP=Ciprofloxacin, OFX=Ofloxacin. Figures in parenthesis are percentages

Table 4: Susceptibility profiles of non-ESBL producing isolates

\begin{tabular}{|c|c|c|c|c|c|c|c|c|}
\hline \multirow[t]{2}{*}{ Organism } & \multicolumn{8}{|c|}{ Antibacterial disc ( $\mu \mathrm{g} / \mathrm{disc})$} \\
\hline & $\begin{array}{r}\text { AUG } \\
(30)\end{array}$ & $\begin{array}{r}\text { CAZ } \\
(30)\end{array}$ & $\begin{array}{r}\text { CRO } \\
(30)\end{array}$ & $\begin{array}{r}\text { CTX } \\
(30)\end{array}$ & $\begin{array}{l}\text { IPM } \\
(10)\end{array}$ & $\begin{array}{l}C N \\
(10)\end{array}$ & $\begin{array}{r}\text { CIP } \\
(5)\end{array}$ & $\begin{array}{c}\text { OFX } \\
\text { (5) }\end{array}$ \\
\hline Escherichia coli $(\mathrm{n}=43)$ & $5(11.6)$ & $24(55.8)$ & $16(37.2)$ & $24(55.6)$ & $37(86.0)$ & $19(44.2)$ & $17(39.5)$ & $18(41.7)$ \\
\hline Klebsiella species $(n=27)$ & $1(3.7)$ & $7(25.9)$ & $6(22.2)$ & $4(14.8)$ & $22(81.5)$ & $2(7.4)$ & $15(55.6)$ & $15(55.6)$ \\
\hline Citrobacter species $(n=5)$ & $1(20.0)$ & $1(20.0)$ & $1(20.0)$ & $1(20.0)$ & $4(80.0)$ & $0(0.0)$ & $2(40.0)$ & $2(40.0)$ \\
\hline Enterobacter species $(n=1)$ & $0(0.0)$ & $0(0.0)$ & $0(0.0)$ & $0(0.0)$ & $1(100.0)$ & $0(0.0)$ & $0(0.0)$ & $0(0.0)$ \\
\hline Proteus mirabilis $(n=11)$ & $2(18.2)$ & $9(81.8)$ & $10(90.9)$ & $8(72.7)$ & $4(36.4)$ & $9(81.8)$ & $3(27.3)$ & $7(63.6)$ \\
\hline Proteus vulgaris $(\mathrm{n}=10)$ & $2(20.0)$ & $3(30.0)$ & $6(60.0)$ & $4(40.0)$ & $6(60.0)$ & $5(50.0)$ & $4(40.0)$ & $2(20.0)$ \\
\hline Providencia species $(n=6)$ & $1(16.7)$ & $4(66.7)$ & $4(66.7)$ & $4(66.7)$ & $5(83.3)$ & $3(50.0)$ & $2(33.3)$ & $2(33.3)$ \\
\hline Acinetobacter species $(n=11)$ & $2(18.2)$ & $6(54.5)$ & $9(18.8)$ & $5(45.5)$ & $7(63.6)$ & $5(45.5)$ & $4(36.4)$ & $4(36.4)$ \\
\hline Pseudomonas aeroginosa $(n=14)$ & $0(0.0)$ & $6(42.9)$ & $8(57.1)$ & $1(7.1)$ & $10(71.4)$ & $8(57.1)$ & $6(42.9)$ & $6(42.9)$ \\
\hline
\end{tabular}

Number tested, AUG= Amoxicillin-clavulanate, CAZ=ceftazidime, CRO=Ceftriaxone, CTX=Cefotaxime, PM=Imipenem, CN=Gentamicin, CIP=Ciprofloxacin, OFX=Ofloxacin.

Figures in parenthesis are percentages 
$[11,17]$, where $\mathrm{CTX}-\mathrm{M}-15$ was reported to predominate [11]. CTX-M-15, CTX-M-3 and CTX-M-2 have been reported as the predominant CTX-M type of ESBL from previous studies $[11,17,18]$. Molecular studies are needed to determine which ESBL type predominates in our locality as the previous studies in south-west geo-political zone of Nigeria.

A total of $102(44.3 \%)$ of the 230 Gram negative bacteria isolates produces ESBL. This is higher than the $2.7 \%, 15.8 \%, 20 \%$ and $28.9 \%$ reported in previous studies in Nigeria $[8,12,18,19]$. Previous use of antimi-crobial agents, especially cephalosporins and fluoroquinolones, has been reported as risk factors associated with emergence of ESBL $[6,7]$. Both antimicrobial agents are the drug of choice in treating Gram negative bacterial infections [8]. Unregulated use of antibiotics and over the counter sales of antibiotics without prescription is rife in Nigeria [9-11]. The cumulative effect of these over time may have been responsible for this high prevalence.

There was no significant difference in the prevalence of ESBL production between Gram negative bacterial isolates recovered from wounds and urinary tract infections. Gram negative bacteria cause a significant number of infections in Nigerian hospitals and represent the majority of both wound and urinary isolates, which form the largest group of clinical specimens received in microbiology laboratories [11]. This indicates that unregulated use of antibiotics for treating infections from these two sites may be rife. Indeed, cephalosporins and fluoroquinolones (risk factors associated with ESBL production) are used as drugs of choice in treating infections caused by Gram negative pathogens [8] which may explain the findings in this study.

The finding that Gram negative bacteria from wound and urine specimens produce ESBL agrees with previous reports [5,19]. Enterobacter species were the most prevalent producers of ESBL generally and from both wounds and urinary tract infections as previously reported from this study locality [12] and disagrees with others which reported Escherichia coli and Klebsiella species as the predominant producers [20]. The reason for this is unclear. The prevalence of ESBL did not differ significantly between Gram negative bacteria recovered from in-patients and out-patients $(p=0.1833)$. An earlier study from the same facility that consisted of bacterial isolates from female reproductive tract did not observe higher antibacterial resistant among isolates from in-patients compared to their out-patient counterparts [21]. However, it has been reported that the highest volumes of antibiotics are being prescribed and consumed in ambulatory care [22] which would have resulted in higher prevalence of ESBL among out-patients isolates. Thus, the unregulated use of antibiotics in the facility may explain the findings in this study.

The susceptibility profiles of ESBL-producing Gram negative bacteria revealed imipenem to be the most active antibacterial agent. Imipenem is not affected by ESBL and this may explain the finding in this study. Gentamicin and fluoroquinolones used in this study were poorly active against ESBL producers. Genes coding for CTX-M type of ESBL have been reported to be associated with plasmids that code for resistance to tetracycline, aminoglycosides and quinolones [8]. Phenotypically, the CTX-M types of ESBL were more prevalent in this study and this may explain the poor activity of gentamicin and the fluoroquinolones used in this study to ESBLproducing Gram negative bacteria.

Although amoxicillin-clavulanate, ceftazidime, ceftriaxone and cefotaxime showed in vitro activity against some ESBL-producing isolates, ESBL enzymes have been reported to confer resistance to all penicillins and cephalosporins [23]. ESBL-mediated resistance is not obvious in disc or dilution susceptibility testing but is associated with clinical failure $[12,13]$. This may explain the result of their disc susceptibility testing results. Susceptibility profiles of nonESBL-producing isolates reveal poor to high activity while Imipenem was the most active antibacterial agent. The finding confirms that ESBL-producing Gram negative bacteria are more resistant than their non-ESBL-producing counter parts.

The limitation of this study is that molecular technique was not applied in the evaluation as there are some type of ESBL that can only be detected by molecular means and not the phenotypic means used in this study.

\section{CONCLUSION}

A high prevalence $(44.3 \%)$ of ESBL production among Gram negative bacteria is reported in this study. Enterobacter species were the predominant producers of ESBL and ESBLproducing isolates were more resistant to antibacterial agents. Prudent use of antibacterial agents is advocated. 


\section{REFERENCES}

1. Gayathri D, Eramma NK, Devaraja TN. New Delhi metallo-beta-lactamase-1: Incidence and threats. Int. J Bio Med Res 2012; 3 (2): 1870 - 1874.

2. Yusuf I, Arzai AH. First detection of carbapenemases producing clinical bacterial pathogens in Kano, Nigeria Biol. Environ. Sci. J. Trop. 2011; 8 (3): $163-$ 167.

3. Jacob GA, Munoz-Price LS. The new $\beta$-lactamases. $N$ Engl J. Med. 2005; 353; $380-391$.

4. Thompson KS. Extended -spectrum- $\beta$-lactamases, AmpC and carbapenemase issues. J. Clin Microbiol 2010; 48 (4): 1019 - 1025.

5. Chatterjee M, Banerjee M, Guha S, Lahiri A, Karak K. Study of drug urinary isolates in an urban hospital setting in Eastern India. Sri Lankan J. Infect Dis. 2012; 1 (2): $36-41$.

6. Knudsen JD, Andersen SE. for the Bis pebjerg Internation Group. A multi-disciplinary intervention to reduce infections of ESBL- and AmpC-producing Gram negative bacteria at a university hospital. PLOS ONE 2014; 9 (1): e86457.doi:10.137/journal.pone. 0086457

7. Soraas A, Sundsfjord A, Sandven I, Brunborg C, Jenum $P A$. Risk factors for community-acquired urinary tract infections caused by ESBL-producing enterobacteriaecae - a case-control study in a low prevalence country. PLOS ONE 2013; e69581.doi:10.1371/ journal. Pone. 0069581.

8. Ogbolu DO, Daini OA, Ogunledun A, Alli AO, Webber MA. High levels of multidrug resistance in clinical isolates of Gram negative pathogens from Nigeria. Int J. Antimicrob Agents 2011; 37 (1): 62 - 66.

9. Okeke IN, Lamikaran A, Edelman R. Socio-economic and behavioural factors leading to acquired bacterial resistance to antibiotics in developing countries. Emerg Infect Dis 1999; 5 (1): 18 - 27.

10. Omoregie R, Eghafona NO. Urinary tract infection among asymptomatic HIV patients in Benin City. Nigeria. $\mathrm{Br}$ J. Biomed Sci. 2009; 166 (4):190 - 193.

11. Ogbolu DO. Impact of ESBLs and CREs - the Nigerian experience. APUA News Letter 2013; 31 (2): 15 - 16.

12. Omoregie $R$, Igbarumah IO, Egbe CA, OgefereHO, Ogbogu PI. Prevalence of extended spectrum $\beta$ lactamase among Gram-negative bacteria isolated from surgical wound and blood stream infections in Benin City, Nigeria. NZJ Med Lab Sci 2010; 64: 74 76.
13. Livermore DM, Brown DF. Detection of $\beta$-lactamasemediated resistance. J Antimicrob chemother 2001; 48 (1): $59-64$.

14. Barrow GI, Feltham RKA. Cowan and Steel's manual for the identification of Medical bacteria 3rd edn. Cambridge University Press, Cambridge. 2003; 1 331.

15. Andrews JM. BSAC standardized disc susceptibility testing method (version 8). J Antimicrob chemother 2009; 64 (3): 454 - 489.

16. Kadar AA, Kumar AK. Prevalence of extended spectrum $\beta$-lactamase among multidrug resistant Gran negative isolates from a general hospital in Saudi Arabia. Saudi Med. J. 2004; 25:570 - 574.

17. Soge OO, Queman AM, Ojo KK, Adeniyi BA, Roberts MC. CTX-M-15 extended-spectrum $\beta$-lactamase from Nigerian Klebsiella pneumonia. J Antimicrob Chemother 2006; 57: 24 - 30.

18. Ogbolu DO, Alli OA, Olanipekun LB, Ojo OI, Makinde OO. Faecal carriage of extended-spectrum betalactamase (ESBL)-producing commensal Klebsiella pneumonia and Escherichia coli from hospital out patients in southern Nigeria. Int J. Med Sci 2013; 5 (3): $97-105$.

19. Aibinu IE, Oghaegbulam VC, Adenipekun EA, Ogunsola FT, Odugbemi TO, Mee BJ. Extended-spectrum $\beta-$ lactamase enzyme in clinical isolates of Enterobacter species from Lagos, Nigeria. J. Clin. Microbiol 2003; 41 (5): $2197-2200$.

20. Alipourfard I, Nili NY. Antibiogram of extended spectrum beta-lactamase (ESBL) producing Eschierichia coli and Klebsiella pneumoniae isolates from hospital samples. Bangladesh J. Med Microbiol 2010: 4 (1): $32-6$.

21. Omoregie R, Egbe CA, Igbarumah IO, Ogefere H, Okorie $E$. prevalence and etiologic agents of female reproductive tract infection among in-patients and out-patients of a tertiary hospital in Benin City, Nigeria. North Am J Med Sci 2010; 2 (10): 473 - 477.

22. Adrienssons $N$, Coenon $S$, Versporton A, Muller $A$, Minahi G, Faes C, Vankerckhoven V, Aerts M, Hens $N$, Molenbergs $G$, Goossens $H$. On behalf of the ESAC project Group. European surveillance of antimicrobial consumption (ESAC): Outpatient antibiotic use in Europe (1997 - 2009). J Antimicrob Chemother 2011; 66 (6): vi 3 - vi 2.

23. Cormican MG, Marshall SA, Jones RN. Detection of extended-spectrum $\beta$-lactamase (ESBL)-producing strains by the $E$ test ESBL screen. J. Clin. Microbiol 1996; 34: $1880-1884$. 